\title{
Educational Dialogue in the Conditions of Edification of Primary Education: Axiological Aspect
}

\author{
Inna P. Yashchuk ${ }^{1}$ \\ Vira O. Vykhrushch ${ }^{2 \rtimes}$ (D) \\ Ivan S. Rusnak ${ }^{3}$ iD \\ Tetiana O. Sharhun ${ }^{4}$ (D) \\ Maryna S. Vasylyk ${ }^{5}$
}

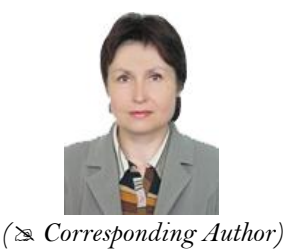

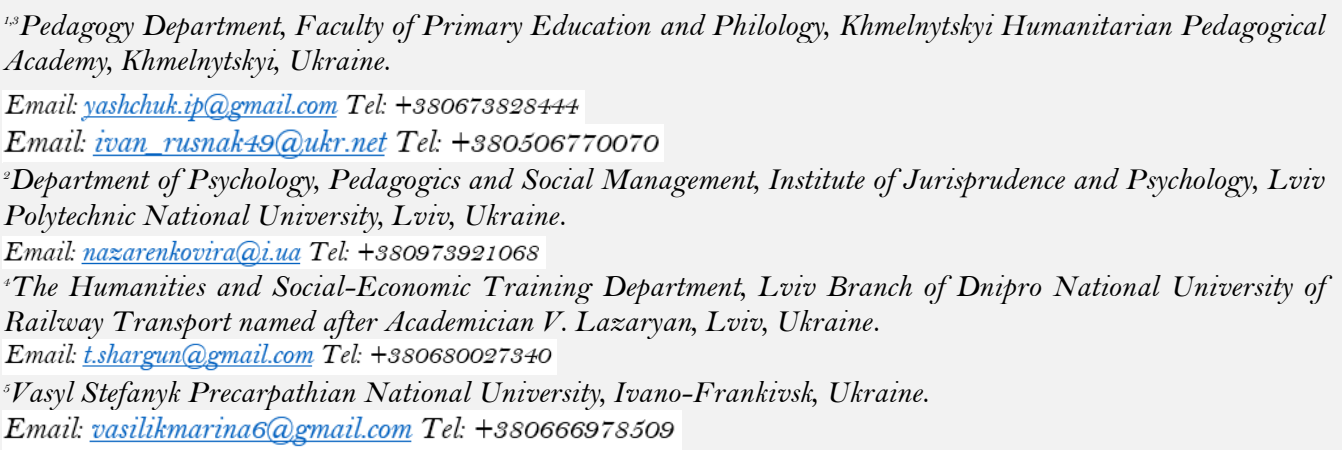

\section{Abstract}

The article presents an empirical research of the problem of educational edification in the axiological plane, analyzes scientific literature, history, and strategies of edificatory changes in response to contemporary challenges in primary education, substantiates the features of cultural and historical and pedagogical processes related to the changes in pedagogical mentality in the context of edification and the new paradigm of education. The essence of edifying changes in the sphere of human culture and educational activity as a part of this culture are analyzed, including systematized general historical and pedagogical and general pedagogical foundations of edification in elementary education through educational dialogue as the means of active formation of a personality of the younger student. It is established that valuable and epistemological anthropocentrism determine the specifics of social philosophical analysis of the role of humancentric education, that sociocentrism of the sociological approach promotes the integration of modern theories into a unified methodological educational strategy, and that in the world a hermeneutical-dialogical tradition has been created, according to which a person develops through action and dialogue that which connects him with culture and the world. The credibility of the research results was confirmed by means of a Mann-Whitney U-test and the accuracy criterion for the differences of averages of the student's t-test for independent selections. On the basis of the research conducted the problems and directions are defined, and strategic, general pedagogical means of changes bringing edification through educational dialogue in primary education are outlined as an effective direction of its reformation.

Keywords: Edification, Educational system, Elementary/primary education, Younger student, Educational dialogue, Dialogic speech, Edification technology, Communicative component, Collective forms of educational activity.

Citation | Inna P. Yashchuk; Vira O. Vykhrushch; Ivan S. Rusnak; Tetiana O. Sharhun; Maryna S. Vasylyk (2020). Educational Dialogue in the Conditions of Edification of Primary Education: Axiological Aspect. Journal of Education and e-Learning Research, $7(4): 342-352$.

History:

Received: 13 July 2020

Revised: 17 August 2020

Accepted: 21 September 2020

Published: 6 October 2020

Licensed: This work is licensed under a Creative Commons

Attribution 3.0 License (cc) EY

Publisher: Asian Online Journal Publishing Group
Acknowledgement: All authors contributed to the conception and design of the study.

Funding: This study received no specific financial support.

Competing Interests: The authors declare that they have no conflict of interests.

Transparency: The authors confirm that the manuscript is an honest, accurate, and transparent account of the study was reported; that no vital features of the study have been omitted; and that any discrepancies from the study as planned have been explained.

Ethical: This study follows all ethical practices during writing. 
Contents

1. Introduction

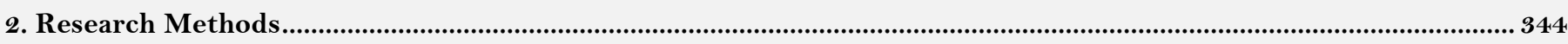

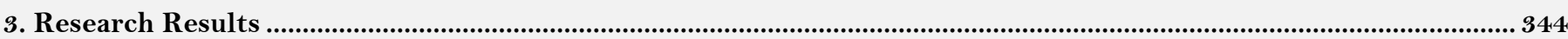

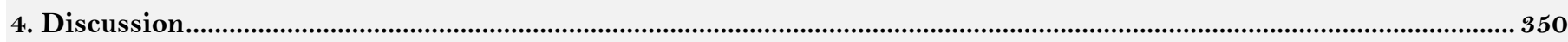

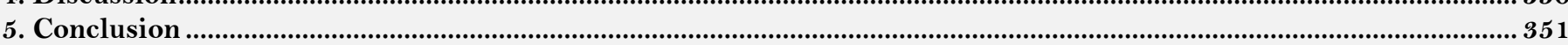

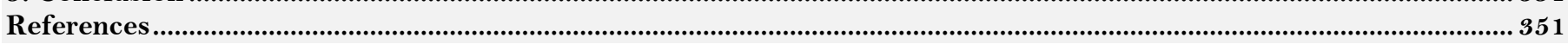

\section{Contribution of this paper to the literature}

This paper contributes to existing literature by offering an empirical research of the problem of educational edification in the axiological plane, analyzes scientific literature, history, and strategies of edificatory changes in response to contemporary challenges in primary education, substantiates the features of cultural and historical and pedagogical processes related to the changes in pedagogical mentality in the context of edification and the new paradigm of education.

\section{Introduction}

Essential characteristics of the educational paradigm that arose as a result of the scientific revolution of the XVII-XVIII centuries are scientism, linear character, use of monologues, authoritarianism, and use of mechanics. The same qualities are inherent in the rational type formed by the appropriate model of education, which, being one of the major means of broadcasting culture and socialization of individuals, is always determined by the model of culture. Modern transformation of culture inevitably undergoes significant changes in the education system, forcing it to search for new ideas both in philosophy of education and in pedagogy, in particular regarding the change of the "Cartesian" type of teacher.

The new pedagogy is called "critical pedagogy," and its representatives expose modern school-formed methods of education to severe criticism. They specify that the main purpose of pedagogical activity in the current education system is to adapt children to existing forms of government, an element of which is the modern school. Scholars are concerned about the prevailing technocratic approach in the pedagogical space and the lack of critical attitudes of the teachers themselves to their own educational practice (Felton \& Kuhn, 2001; Sedova, Sedlacek, \& Svaricek, 2016). It was pointed out that school does not form a child's perception of the experience as a result of active, cognitive activity, and we reject such an approach that seeks to master and hone productive communicative pedagogical technologies (Nelson, 2017).

At the same time, the history of the development of cultural models of education is determined not only by socio-cultural prerequisites, but also relies on the humanistic traditions of national and foreign philosophy, pedagogy, and psychology. Developed in the 17th century, the educational paradigm of the eminent Slavic thinker Komenskyi is a system of universal education of the whole human race (Antonenko \& Bezugla, 2017). A distinguishing feature of the philosophical and pedagogical views of this prominent humanist was that he regarded education as one of the most important prerequisites for establishing fair and friendly relationship between humans and nations. This idea was called "panpedia" or "world education." Central in this theory is the substantiation of ideas about the need for people to be able to live in peace with others, fulfill mutual obligations, and respect and honor traditions (Antonenko \& Bezugla, 2017).

The roots of the theories of universal upbringing and education are found in the philosophical and pedagogical heritage of the nineteenth and twentieth centuries. The spiritual doctrine of Living Ethics, proclaimed by Roerich, who initiated the conclusion of an international legal act on the protection of cultural values, became a peculiar branch of Slavic philosophical and pedagogical opinion (Department for Education, 2013). His idea about unification of cultures, which creates favorable conditions for human cooperation, relies on anthroposophy and the philosophy of cosmism (Department for Education, 2013). The scientist emphasized the need for the synthesis of Slavic, western and eastern cultures and civilizations, science and religion, and the natural evolution of space, man, and all mankind as its organic parts. The philosophical, social, and pedagogical meaning of such a doctrine is in enlightening and updating of a person, leading him to the path of cooperation and creative activity. Human activity is moral insofar as it implements the ideas of common welfare, active cooperation, and the unity of cultures and civilizations.

Modern researchers talk about the negative consequences of the departure of civilization from culture, emphasizing that civilization is the substitution of life goals by means of life, by the mechanics of life (Macbeth, 2011). The ratio between goals and means of life is mixed and distorted (Maton, 2013).

Culture means the connection of people, civilization is the force of things (Mercer \& Littleton, 2017).

Philosophical foundations of human-centered education, essential aspects of human interaction with the outside world, are reflected in researches of the twentieth century, in particular in the concepts of R. Artfield (global ecological humanistic ethics) (Wu, 2013; Yun-Jo \& Reigeluth, 2012). Both valuable and epistemological anthropocentrism, that makes specifics of the social and philosophical analysis of the role of human-centered education, and sociocentrism of the sociological approach, can be integrated into a single methodological strategy. There was a tendency toward problematic, but not substantive, development of psychological and pedagogical knowledge, reflecting the interdisciplinary nature of research in the field of education (Littleton et al., 2010).

It is important to note that education, as a part of culture, is considered in two different interpretations: cultural-centric and anthropocentric. The cultural-centric approach interprets education through objects and products of cultural development, i.e. through the sights of spiritual and material culture. For the anthropocentric element, the main thing is life of culture, its development, and the role of man in it. Therefore, the key problem in defining the essence of education as a part of culture is seeing a person in culture as an object and subject of creative activity, a person in the process of development, self-determination, and self-identification. In this connection, the claim is that sources and determinants of human mental development are in culture that historically evolves and is assimilated in the process of dialogue. 
Interpretation of culture as an integral human activity, on the basis of which spiritual self-identification is carried out, the self-determination of our consciousness and thinking, is based on the statement that the sense of education must be understood in a new way. When the perceived center of this phenomenon is "a person of culture," the relationship between culture, education, and person as a dialogue of cultures is considered as "communication of consciousness," and the main goal of education is the formation of constructive relations, which at the same time create necessary conditions for complete development and professional formation of the person (Alexander, Hardman, \& Hardman, 2017).

The aim and goals of the research are to study and analyze the cultural, historical, and pedagogical processes related to the change of pedagogical mentality in conditions of edification and the new paradigm of education, in particular, subjectivities of the student and the teacher as participants in didactic interaction of a new type and subjects of educational dialogue.

\subsection{Objectives of the study}

1. To analyze the essence of edifying changes in the sphere of human culture and educational activity as part of this culture.

2. To systematize the general historical and pedagogical and general pedagogical foundations of edification in the field of primary education through educational dialogue.

3. Tn the basis of the system of diagnostic methods, to determine the nature of the influence of the edification of primary education by ensuring educational dialogue of its subjects.

4. To outline strategic general pedagogical means of edificatory change through educational dialogue in primary education as an effective direction for its reforming.

\section{Research Methods}

In the process of experimental research, the following methods were used:

1) Theoretical-comparative-historical analysis of philosophical, psychological-pedagogical, and sociological literature on the problem of research, generalization of historical-pedagogical material on the problem of educational edification, and content analysis.

2) Diagnostic-observation, questioning, testing, and peer review.

3) Data processing methods-descriptive statistics, mathematical and statistical analysis (the Mann-Whitney Utest), and the statistical significance test (Student's t-test).

4) Interpretative-systematization, generalization, and qualitative-content analysis of the obtained results. Diagnosis of effectiveness of the conducted research was carried out using the following methods:

- Balanced Emotional Empathy Scale - BEES by Megrabian and Epstein.

- Ovcharova's technique for identification of students' communicative tendencies.

- $\quad$ CBS one test-questionnaire for the study of communicative and organizational skills (soft skills).

- CD-Spielberg and Hanin test-questionnaire to assess the level of reactive and personal anxiety.

- Test for self-assessment by Tsymbaliuk and Lozhkin.

- Methods of diagnostics of "obstacles" in establishing emotional contacts (according to Boyko).

- Questionnaire to identify communicative problems of younger students.

- Methods of observation of children.

- Conversations with parents and teachers of children under study.

These diagnostic techniques are reflected in Chala and Shakhraychuk (2018). The outlined list of methods was adapted by the author according to the subject of research.

The research was conducted from 2014 - 2019 by examining comprehensive schools in Kharkiv, Ternopil, Mykolaiv, and Chernivtsi (Ukraine). The demographic involved was 270 students and 18 teachers.

\section{Research Results}

Among various approaches to the historical and pedagogical analysis of the problem of educational dialogue in the domestic pedagogy of the second half of the XXth to the beginning of the XXIth century, considerable interest was shown by those who are oriented to the manifestation of the subjectivity of the position of the teacher and the child in an educational situation, to the identification of theoretical and subjective activity, as well as how the subject-subject interaction (cooperation) of the teacher and students influences the formation of their personal qualities. The historical and pedagogical section of evolution of the problem of educational dialogue is impossible without analysis of its psychological basis as the background on which, and in parallel with which, the idea of dialogue in the general pedagogical and didactic plane was formed.

According to exchange theory (Chai, Koh, Tsai, \& Tan, 2011), people interact with each other on the basis of their experience, weighing possible gains and expenses. From the standpoint of symbolic interactionism, people's behavior towards others and objects of the world around them is determined by the value they attach to them (Claro et al., 2012). The theory of impression management is based on the claim that the social interaction situation is reminiscent of a dramatic performance in which actors seek to create and maintain a favorable impression Claro et al., 2012). There is an experimental attempt to reduce the analysis of the substantive aspect of interaction to research the process of interaction of people in the dyad.

The results of researches within the theory of "dyadic interaction" by Thibault and Kelly have demonstrated low efficiency of experimental study of only the form to understand the process itself (Darling-Hammond \& Bransford, 2005; Pisanu \& Menapace, 2014). One example of an implicit-dialogical study of personality psychology is the concept of personality consciousness, the concept of the structure of the image "I" and the "Iconcept" of personality, an important characteristic of which is the recognition of the multiplicity of their structural components.

Concerning the above theories, it should be noted that their incomplete list gives an idea of the diversity of analysis of interpersonal interaction and reveals the wide opportunities of dialogical competence that can be 
formed within the educational activities of elementary school students. Theoretical analysis of the problem of activity allows us to determine some basic social and psychological parameters of a system of development of a collective in a general view. Such parameters, according to the scientist, are:

- Over-situational activity of the collective members, that is, their social activity.

- A measure of openness of collective, that appears, in particular, in emotional identification with the new members of collective, in relation to "others" as "to their own".

- A reflection of the movement of collective that can be called a self-criticism phenomenon.

In the training team, these parameters have their own specificity at each stage of personality development. Therefore, the problem of personality activity becomes inseparably linked to the problems of team development and joint activity in the form of general work. All three basic concepts with which we operate: student personality, educational activity, and the teaching staff have a single substantial basis that follows from the characteristics of social and historical human practice.

On the other hand, the most important feature of the culture of modern times, and therefore of the elementary education system, is its monologue (Haneda, Teemant, \& Sherman, 2017). Education, in turn, aims to illuminate the reality and the future, and the role of the teacher comes down to their ability to lead the student in the shortest way from ignorance to knowledge, from questions to answers, from deception to the truth that he knows. The teacher acts as a representative of the mind; he transmits knowledge, controls the correctness of assimilation, and evaluates. The teacher has a monopoly on truth, which is also unambiguous and indisputable. The final assessment is determined by the measure of development of ready knowledge. The teacher's position in such a situation is inevitably authoritarian. If there is a dialogue, then it becomes hierarchical in nature: from the bottom up, or from top to bottom (Hennessy et al., 2016).

Another characteristic of the model of modern education is its mechanical character. Naturally, the model of education is an idealization and is not found anywhere in its purest form. Moreover, a talented teacher always strives to go beyond the educational paradigm and even to destroy it. The typical arithmetic teacher of the Cartesian model perceives a student as a reservoir that needs to be filled with knowledge, knowledge - as a readymade product of science, and himself as a conductor, transmitting knowledge, or a person who controls this process (Hennessy, Dragovic, \& Warwick, 2017).

The technocratic direction regards the teacher as the leader and the superintendent; the teacher's role is measuring the achievements of the students and managing their behavior, while the students are given the role of management objects. At the same time, the visual (computer) revolution requires the formation of another type of mind capable of interpretation, understanding of various semantic meanings, and to orientation in a complex, organized informational space. It determines the need to replace the directive mind with the hermeneutic (Howe \& Abedin, 2013).

Felton and Kuhn (2001) demonstrate the roles of the principles of anthropologism and dialogism in education, the problem of forming dialogical thinking, and a tolerant anthropological outlook by experts is formulated. It has been shown that dialogue is a way to action the main educational goals of self-awareness, self-understanding, selfdevelopment, and self-determination of personality. Dialogue, according to Felton and Kuhn (2001), requires sacrifices. These sacrifices are self-determination and self-improvement, because to accept the culture of another, to tolerate its culture next to him, can only be one to whom dialogical thinking is available; the ability to communicate with oneself as with others, with their mind. Human-centered education and upbringing in the modern sense is an edification, the process of forming oneself through dialogue, hermeneutical discourse, and thus understanding oneself and others. At the intersection of philosophy, sociology, psychology, pedagogy, cultural studies, and anthropology, a new field of interdisciplinary knowledge has emerged, a multidisciplinary theory of education called educology (Lefstein \& Snell, 2014).

In connection with the challenges of modern society the new term edification was introduced for a more exact designation of the process of formation oneself through dialogue, because they believed that education sounded too simplified. Edification, they believe, is a form of hermeneutic discourse that establishes various connections between our own culture, or discipline, and other cultures. Rorty (1979) distinguishes between two types of education: adherence to existing traditional culture and, actually, edification, adherence to the diversity of modern culture through independent efforts and with awareness of the results of one's own experience and reflections.

The starting point for establishing the forms of education that carry dismissal is the direct life world of the individual. To teach means to show how values embodied in the structures of everyday life limit the thinking and behavior of man. Because a person who has to overcome his or her dependent position is often suppressed and depressed to such an extent that his or her daily experience seems to be the only possible one, it is necessary that the teacher, acting as coordinator and co-investigator, helps the student to capture his or her life situation in a certain way (Littleton \& Mercer, 2013). This process of fixation, which the author contrasts with other work, far from his own interests. Programs that have no relation to the life experience of students and compels them to take a detached view of themselves, of those structures of personality developed under the influence of external social conditions, were unconsciously borrowed from outside.

Through a dialogue involving all the participants in the learning process, it is possible to pass from passively accepting the situation to critically reflecting on what was previously perceived as indisputable. The concepts formulated here help to comprehend changes and realize the need to transform reality, and since new difficult situations emerge, their process of awareness must be started again and again.

Thus, Howe \& Mercer (2017) are unanimous in the main elements:

- Education should be, first of all, a practice of freedom; at first overthinking and discussing life situations, and then in socially significant action.

- The aim of all pedagogical efforts should be the life world of the student, an integral element of the culture of which is critical thinking.

- Dialogue (polylogue) is an adequate means of achieving this goal.

- In postmodern society, education is the most important instrument for its transformation; a prerequisite for getting out of a civilized crisis and a condition for preventing anthropological catastrophe. 


\subsection{Theoretical and Methodological Component of the Research}

The carrier of a new type of rationality is a person of culture, namely a teacher-hermeneutic who is capable of working not only with knowledge, but also with various cultural situations, different thinking styles, with ideas of different cultures and different mental structures. The formation of a person of culture is defined by the relevant tasks of an educational system.

This new type of teacher is characterized by a number of determinants and is caused by the emergence of a fundamentally new behavior, not related to the specific content of the subject, whose function is not to manipulate information, but to create a certain cultural situation which generates the ability to work with meanings and creates a new type of thinking. Its most important task is to form a culture of understanding and expand personal creative potential. The foundational activity of this type of teacher was laid down in antique Greece. At the origin of this tradition was Socrates. The teacher - maieutic - guides the student into the culture, organizes the dialogue of cultures, leads the student through meaningful labyrinths, and immerses the student in personal, ethnocultural, religious, esthetic, moral, and other worlds. The result of this immersion is not just intellectual knowledge, but knowledge filled with ideological values; knowledge is existential.

The task of the teacher-maieutic is to guide the student through the points of wonder, to enter into an existentially significant situation, to force them to solve ideological questions, to create aporias, to confront antinomies, and to ask questions that have not yet been answered. Only children and sages ask questions whose answers are known to all, so the questions of children and sages must be the basis for search of the truth.

The postmodern principle of the rejection of unambiguous decisions, the refusal to receive absolute knowledge (knowledge in the ready form), was the basis of the Socratic conversations. Maieutics should involve the student in the situation of problems and doubts, that is, help him to open up to the world, to turn him to the problems of being (universal and his own), to touch on the meaning of life, and to be open to the student points of intensity. All knowledge, especially humanitarian, must be passed through these points (Aguiar, Mortimer, \& Scott, 2010). Dialogue, Socratic conversations, imply the personal character of communication, the activity of thinking, and the openness of interlocutors to each other. Therefore, the basis of communication should not be the logic of the content of the subject, but the logic of culture, philosophy of culture, and human activity.

Considering the above, in January 1987 at the first all-union conference of teachers-dialogists at the institute of general and pedagogical psychology of the Academy of Pedagogical Sciences of the USSR, the report "Dialogue of cultures and school of the 21 st century" was heard, in which the basic ideas of school of dialogue of cultures, school programs, and main stages of study are substantiated and developed. Similar conferences and seminars took place in the Institute until 1991, and also in 1991-1994-during the school holidays several times a year both in Russia and Ukraine. Based on jointly developed ideas, work was carried out in a number of schools in Ukraine. Among them there were schools in Kharkiv (director V. Lytovskyi and others), Kiev (director A. Volynets) and Zaporizhzhia (Zaporizhzhia kollegium). A large seminar on the theory and practice of the school of dialogue of cultures, as well as on the philosophy of the dialogue of cultures, was held in Kyiv every six months with the participation of representatives of Russian, Kharkiv, and Kyiv schools, on October 26-29, 2005, April 27-31, 2006, October 29, 2006, April 26-30, 2007, June 1-4, 2009, and June 7-10, 2012. The active participants of the Kiev group today are A. Volynets, L. Bogachyk-Volynets, S. Kopylov, Sh. Ishakov. At different stages of activity V. Groisman, T. Morozovska, V. Dyshliuk, I. Dyshliuk, V. Shelest, N. Marchuk, V. Titov and others joined this group.

The substantial component of the research., the purpose of the use of edification technology, is to help younger students to develop communication skills; to successfully and fully realize themselves in communicative activities.

In the practice of the modern elementary school, and the strategy of teacher's activities as organizers of didactic interaction, it is necessary to distinguish between educational dialogue and conversation as a dialogue in the study Table 1. These approaches are connected to different strategies of teacher activity; the subject of the learning process.

\begin{tabular}{l|l|l}
\multicolumn{2}{c}{ Table-1. Comparative characteristics of strategies of teacher activity as a subject of the learning process. } \\
\hline Indicators & Conversation as a dialogue in learning & Educational dialogue \\
\hline Major goal & $\begin{array}{l}\text { Establishing how students learned specific } \\
\text { facts, remembering what is necessary for } \\
\text { further learning }\end{array}$ & $\begin{array}{l}\text { In the process of collective learning new } \\
\text { knowledge is opened, the problem is solved, the } \\
\text { algorithm of the task accomplishment is } \\
\text { established }\end{array}$ \\
\hline $\begin{array}{l}\text { Correct } \\
\text { formulation of } \\
\text { questions }\end{array}$ & $\begin{array}{l}\text { Reproductive questions that are formulated } \\
\text { with the words "remember," "name," "give } \\
\text { examples" }\end{array}$ & $\begin{array}{l}\text { Reproductive questions. Problem questions that } \\
\text { begin with "why", "what for", "why", questions- } \\
\text { reflections }\end{array}$ \\
\hline
\end{tabular}

However, the organization of dialogue in the classroom often remains a problem. Calls for dialogue are often merely calls, often come down to insignificant conversations or reasoned discussions that are a kind of linguistic fetishization (a subject of blind imitation). Incorporating the ideas of educational dialogue into pedagogical practice is very complicated, and it demands not mastering the prescription in reality of these or other techniques but mastering each new situation in a new way. Within the methodical organization of the lesson the necessary pedagogical style of communication must be chosen, which allows us to create psychologically comfortable conditions for communication with children (Hennessy et al., 2017; Howe \& Abedin, 2013). They are stipulated by models of the teacher activity in a methodical context of organizing lessons at elementary school Table 2 . 
Table-2. Comparative characteristics of models for the construction of educational activity: an edification component.

\begin{tabular}{|c|c|c|c|}
\hline Indicators & Authoritarian model & Leader model & Partner model \\
\hline $\begin{array}{l}\text { Studying of a } \\
\text { new subject }\end{array}$ & $\begin{array}{l}\text { - } \text { reports a subject; } \\
\text { - formulates the purpose; } \\
\text { - } \text { offers exercises; } \\
\text { explains the course of } \\
\text { execution; } \\
\text { - formulates conclusions; } \\
\text { - focuses students to full } \\
\text { reproduction } \\
\text { apprehension }\end{array}$ & 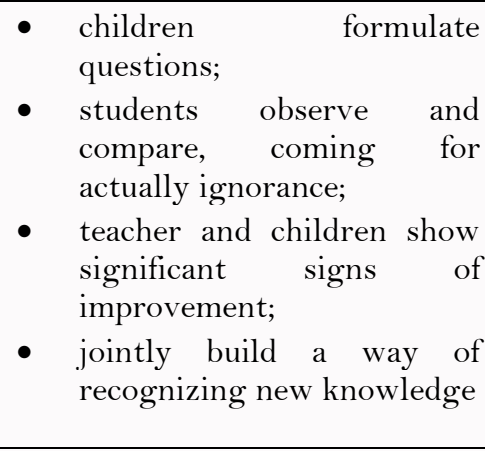 & $\begin{array}{l}\text { - } \\
\text { and didactic task on the basis } \\
\text { of analysis of educational } \\
\text { material; } \\
\text { children plan a way of solving } \\
\text { a learning problem; } \\
\text { - } \text { students make hypotheses; } \\
\text { students study the } \\
\text { educational material and form } \\
\text { new knowledge and way of } \\
\text { working with it }\end{array}$ \\
\hline $\begin{array}{l}\text { Generalization } \\
\text { and } \\
\text { systematization } \\
\text { of the studied } \\
\text { material }\end{array}$ & $\begin{array}{l}\text { - } \quad \text { asks a question; } \\
\text { - } \quad \text { offers children tasks; } \\
\text { - } \quad \text { offers a set of exercises; } \\
\text { requires complete } \\
\text { conceptation of apprehended } \\
\text { - } \quad \text {-draws conclusions }\end{array}$ & $\begin{array}{l}\text { - jointly formulate questions; } \\
\text { - } \quad \text { chooses a form of } \\
\text { generalization; } \\
\text { - } \quad \text { analyze the material; } \\
\text { - formulates conclusions }\end{array}$ & 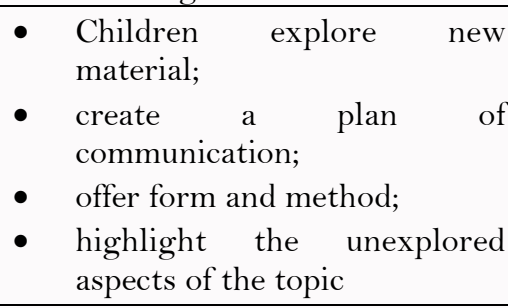 \\
\hline $\begin{array}{l}\text { Content } \\
\text { analysis of the } \\
\text { textbook }\end{array}$ & $\begin{array}{l}\text { - } \text { suggests finding the } \\
\text { required page; } \\
\text { - read the name of the topic; } \\
\text { - } \text { analyzes performance } \\
\text { samples; } \\
\text { - } \text { sets the reception of the } \\
\text { work }\end{array}$ & $\begin{array}{l}\text { - } \text { children consider the } \\
\text { textbook; } \\
\text { - } \text { are guided in its content; } \\
\text { - distinguish the purpose of } \\
\text { each element; } \\
\text { - formulate } \\
\text { questions }\end{array}$ & $\begin{array}{l}\text { - children analyze educational } \\
\text { material in formulating a } \\
\text { topic, didactic problem, } \\
\text { choosing ways to solve it, } \\
\text { generalizing, isolating ways } \\
\text { of working with knowledge }\end{array}$ \\
\hline $\begin{array}{lr}\text { Teaching } & \text { self- } \\
\text { examination } \\
\text { and } \quad \text { self- } \\
\text { control } & \text { to } \\
\text { students } & \end{array}$ & $\begin{array}{l}\text { - } \text { checks itself; } \\
\text { - children carry out mutual } \\
\text { verification; } \\
\text { - encourages children to } \\
\text { check }\end{array}$ & $\begin{array}{l}\text { - jointly developed criteria for } \\
\text { verification and control; } \\
\text { - jointly implement and } \\
\text { change methods }\end{array}$ & $\begin{array}{l}\text { - define criteria and methods of } \\
\text { self-testing; } \\
\text { - adjust, change; } \\
\text { - analyze the results of their } \\
\text { work, establish } \\
\text { inconsistencies and causes of } \\
\text { their manifestations }\end{array}$ \\
\hline $\begin{array}{l}\text { Working with } \\
\text { rule definition } \\
\text { in a textbook }\end{array}$ & $\begin{array}{l}\text { - invites children to read the } \\
\text { rule; } \\
\text { - raises reproductive } \\
\text { questions; } \\
\text { - offers students to repeat the } \\
\text { rule multiple times }\end{array}$ & $\begin{array}{l}\text { - students find the rule, read } \\
\text { it and analyze it; } \\
\text { - answer } \\
\text { questions; } \\
\text { - jointly plan the method of } \\
\text { its application }\end{array}$ & $\begin{array}{l}\text { - students derive a common } \\
\text { rule and compare it with the } \\
\text { one presented in the textbook; } \\
\text { - raise questions to it; } \\
\text { - plan and discuss how to work } \\
\text { with the rule }\end{array}$ \\
\hline $\begin{array}{l}\text { ng with } \\
\text { hmms }\end{array}$ & $\begin{array}{l}\text { - presents the algorithm to } \\
\text { students in a ready-made } \\
\text { form; } \\
\text { - students re-read each step } \\
\text { in the algorithm; } \\
\text { - before exercise, students } \\
\text { reproduce the algorithm } \\
\text { completely }\end{array}$ & $\begin{array}{l}\text { - jointly build an algorithm to } \\
\text { explain the need for action; } \\
\text { - use the algorithm in the } \\
\text { process; } \\
\text { - change and adjust the } \\
\text { algorithm }\end{array}$ & $\begin{array}{l}\text { - output an algorithm and } \\
\text { compare it with the existing } \\
\text { one; } \\
\text { - construct, rework; } \\
\text { - compare with others }\end{array}$ \\
\hline $\begin{array}{l}\text { Working with } \\
\text { illustrations, } \\
\text { diagrams }\end{array}$ & $\begin{array}{l}\text { - asks questions and gives a } \\
\text { task; }\end{array}$ & $\begin{array}{l}\text { - defines their need at a } \\
\text { lesson; } \\
\text { - uses in the solution of an } \\
\text { educational task }\end{array}$ & $\begin{array}{l}\text { - offer different types of work } \\
\text { with the material; } \\
\text { - choose the kind that will help } \\
\text { to solve the educational task }\end{array}$ \\
\hline $\begin{array}{l}\text { Training } \\
\text { ability to study }\end{array}$ & $\begin{array}{l}\text { - offers educational tasks; } \\
\text { - declares educational tasks } \\
\text { and then does not return to } \\
\text { them; } \\
\text { - at the lesson, students move } \\
\text { from one task to another; } \\
\text { - frontal work }\end{array}$ & $\begin{array}{l}\text { - jointly come to set an } \\
\text { educational task, plan its } \\
\text { solution; } \\
\text { - the teacher "leads" children } \\
\text { in solving the problem; } \\
\text { - jointly summarize; } \\
\text { - students formulate } \\
\text { - } \text { educational questions; } \\
\text { - jointly plan the result; } \\
\text { work in pairs }\end{array}$ & 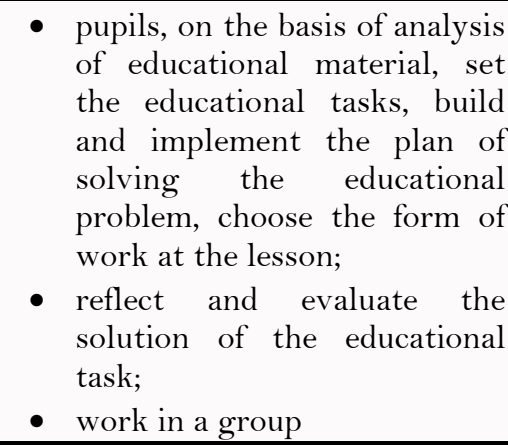 \\
\hline
\end{tabular}

It is obvious that educational dialogue is only possible in the leadership and partnership models of teacher activity. Under such circumstances, both the student and the teacher are concerned with the problem put forward the lesson. For the teacher, it is just as sharp as for the child (Lefstein \& Snell, 2014; Littleton. \& Mercer, 2013). The teacher, along with the students, offers his own, individual solutions to the problem, asks his questions, and creates his images. For students, the dialogue is a sense and understanding of equality with their interlocutor. Equality in dialogue is not equality in knowledge, it is equal rights to be responsible for formulating and resolving your problem. The positive impact of educational dialogue in lessons in the formation of new skills and communicative competence of students is that students communicate for most of the lesson, and the teacher only directs and models various forms of didactic interaction, it involves low-achieving and shy children, students want 
to communicate, the level of motivation at the lesson is very high due to the use of different sources of motivation, and the language and speech levels correspond to the real capabilities of the group.

Researchers in dialogic speech note that its content and form in a child communicating with peers and adults are significantly different. Thus, the dialogues in the system "child - child" are characterized by a more complete and active application of various speech means, clarity, consistency, and correctness in comparison with the dialogues in the system "child - adult". When talking to an adult, the child does not aspire to be understood - the adult understands the child in any situation. Instead, a peer does not try to understand the misunderstanding correctly, he requires that the statement was accurate and clear. The need to communicate with other children encourages the child to engage in speech activity, that is, promotes the development of personality.

The basis for the development and implementation of educational dialogue was the rethinking of the potential of forms of educational activity of younger students as a basis for communication and their optimal combination Table 3 .

Table-3. Characteristics of types of individual and collective forms of educational activity of younger students.

\begin{tabular}{|c|c|c|c|c|c|c|c|c|c|c|c|c|c|}
\hline \multirow[t]{2}{*}{$\begin{array}{lll}\text { Forms of educational } \\
\text { activity }\end{array}$} & \multicolumn{2}{|c|}{$\begin{array}{c}\text { The } \\
\text { content of } \\
\text { the task }\end{array}$} & \multicolumn{3}{|c|}{$\begin{array}{c}\text { Number of } \\
\text { students }\end{array}$} & \multicolumn{2}{|c|}{$\begin{array}{c}\text { The } \\
\text { pace of } \\
\text { work }\end{array}$} & \multicolumn{2}{|c|}{$\begin{array}{c}\text { Level of } \\
\text { basic } \\
\text { preparation }\end{array}$} & \multicolumn{2}{|c|}{$\begin{array}{l}\text { The role of } \\
\text { the teacher }\end{array}$} & \multicolumn{2}{|c|}{$\begin{array}{l}\text { Opportunity } \\
\text { for students to } \\
\text { communicate }\end{array}$} \\
\hline & : & 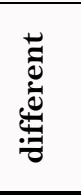 & $\frac{n}{\tilde{0}}$ & $\frac{5}{3}$ & 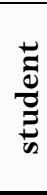 & $\frac{\stackrel{0}{\partial}}{\stackrel{\partial}{g}}$ & : & $\frac{\stackrel{0}{\partial}}{\stackrel{\partial}{ }}$ & 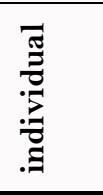 & 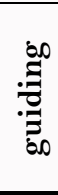 & $\frac{\grave{d}}{\sqrt[\pi]{2}}$ & $\begin{array}{l}\ddot{\Xi} \\
\underset{0}{0} \\
\frac{0}{\pi}\end{array}$ & 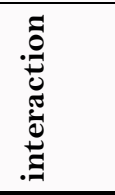 \\
\hline Individual & & + & & & + & & + & & + & + & & + & \\
\hline Individual-Group & + & & & + & & + & & + & & + & & + & \\
\hline Individual-Frontal & + & & + & & & + & & + & & + & & + & \\
\hline Collective and Group & + & + & & + & & & + & & + & & + & & + \\
\hline Collective-Frontal & + & & + & & & & + & & + & & + & & + \\
\hline
\end{tabular}

The essence of the problem-dialogue teaching technology developed by modern scholars (Michaels, O'Connor, \& Resnick, 2008; Pehmer, Gröschner, \& Seidel, 2015; Pontefract \& Hardman, 2005) and adapted by the authors (Ruthven et al., 2017; Sepeng, 2011) in the technology of the optimal combination of individual and collective forms of educational activity is reflected in its dialogical basis: two links should be worked out in the lesson of learning new material - formulation of a learning problem, and finding the means of solving it. The dialogical nature of technology lies in the formulation of a teaching problem, a didactic task, and in searching for ways to solve it by students in the process of specially constructed dialogue.

The main purpose of this technology is to answer the question "How to learn?" and replacing the lesson which contains new material with the lesson of discovering new knowledge.

There are two main links at the lesson of learning new material on technology of problem-dialog learning: the formulation of the problem (the formulation of the topic of the lesson or research problem), and the search for a solution (the formulation of new knowledge). Unlike the practice of mastering something new in the traditionalexplanatory type of teaching, the optimal search for a solution to the problem is that the teacher gradually brings the students to knowledge, either from the formulated problem or without it, during a productive dialogue with the students.

At the stage of the problem statement, problematic dialogue assumes that the teacher creates a problem situation / contradiction, the teacher, with special remarks, helps the student to understand the contradiction and formulate a problem, leading to it step by step, and the teacher helps to find a solution to the problem by building a way to new knowledge.

Encouragement to be aware of contradiction of a problematic situation involves separate questions from the teacher, which stimulate students to understand the contradiction inherent in the problematic situation.

From the whole palette of problematic methods, dialogic methods are the most effective for the technology of problem-dialog teaching with stimulating and preparatory dialogues.

In general, a stimulating dialogue is applied to formulate a learning task, that is to help students identify the topic of the lesson themselves or provide a question that is controversial in nature.

Encouraging dialogue for awareness of a contradiction in a problem situation is a system of teacher questions that encourage students to realize the contradiction inherent in a problem situation and gradually lead them to formulate a topic or knowledge.

The essence of educational dialogue lies in the creation of the educational process so that at its individual stages students could engage in contact not only directly with the teacher, but also with each other through collective forms of educational activity, and that pedagogical influence should not be direct but indirect to put the student in a situation in which he has mastered knowledge with interest. For this purpose, small groups with certain characteristics are created.

Regarding the technological component of the experimental research, the purpose of the experimental part of our study was to study the impact of edification changes in the educational process on the personality of younger students in order to identify the dependence of the development of communication skills of elementary students on the influence of edifying technologies using educational dialogue.

The program of the ascertaining stage of the research included diagnostics of communicative abilities of younger students, exploring emotional states, namely anxiety, and personal factors affecting younger students, 
namely self-esteem. During the 2014-2019 study, 270 students of experimental 1-4th grades of secondary schools in Kharkiv, Ternopil, Mykolayiv, and Chernivtsi (Ukraine) participated. Parallel experiment technology was applied.

Psychological and pedagogical methods were used to study the communicative skills, emotional states, and personal factors of younger students as follows: Ovcharova's method for identification of communicative dispositions of students; a COT 1 test-questionnaire to study students' communicative and organizational skills (soft skills); a test-questionnaire by Spielberg and Hanin to evaluate the level of reactive and personal anxiety; the Balanced Emotional Empathy Scale (BEES) test by Megrabian and Epstein; test for self-assessment of Tsymbaliuk and Lozhkin; a questionnaire to identify communicative problems of younger students; methods of observation of children; and conversations with parents and teachers of children under study.

The results of the research were exposed to correlation analysis using the Mann-Whitney U-test, validation of statistical significance (Student's t-criterion test) and processed using PPP Statistica 5.0.

The use of observation, questionnaires, and a soft skills test questionnaire to study communicative and organizational skills made it possible to discover that the emotional and mental state of junior high school students, attributed to low and below average levels, arise as a result of unconscious correlation of previous learning expectations, and work or personal problems, and generates both uplift, euphoria, and some anxiety associated with fears of various kinds of failure both in educational and interpersonal fields Table 1.

The technique of diagnosting Spielberger's anxiety, Hanin as a reliable and informative means of selfassessment of the level of anxiety at the moment (reactive anxiety as a state), and personal anxiety (as a stable characteristic of a person) showed that at the ascertaining stage of research the level of reactive anxiety in the experimental group is low (56\%) and the dominant level of personal anxiety is medium (54\%). Consequently, purposeful corrective work with younger students is required to correct levels of reactive and personal anxiety, development of reflection, that is, self-knowledge of internal mental acts and states, and the formation of steady positive self-esteem. These characteristics are a prerequisite and a result of the modification of the educational process in primary school.

At the final stage of the experimental research, diagnostics of the communicative abilities of younger students were conducted to determine the effectiveness of the offered edification technology. The purpose of the control research was to identify the impact of educational dialogue on the development of the communicative skills of younger students.

The results of the experimental research at its ascertaining and final stages are presented in Table 4.

Table-4. Summary table of levels of communicative abilities of students at the ascertaining and final stage of the research

\begin{tabular}{l|c|c|c|c|c}
\hline \multirow{2}{*}{$\begin{array}{l}\text { Level of communicative } \\
\text { abilities }\end{array}$} & \multicolumn{2}{|c|}{ Ascertaining stage of the research } & \multicolumn{2}{c}{ The final stage of the research } \\
\cline { 2 - 6 } & marks & Number of people & \% & Number of people & \% \\
\hline Low & 1 & 54 & 20 & 18 & 6,7 \\
\hline Below average & 2 & 48 & 17,8 & 30 & 11,1 \\
\hline Medium & 3 & 72 & 26,7 & 96 & 35,6 \\
\hline High & 4 & 30 & 11,1 & 48 & 17,8 \\
\hline Very high & 5 & 66 & 24,4 & 78 & 28,9 \\
\hline
\end{tabular}

Therefore, as a result of the technology of introducing changes of edification in the educational process by means of educational dialogue, the average group level of communicative skills of younger students has increased by $35 \%$ and organizational abilities by $13 \%$. It is possible to claim that the proposed edification technology, aimed at developing the communicative skills of younger students by engaging in educational dialogue, has a positive impact on improving the level of communicative skills of elementary students.

The hypothesis that a younger student's communication skills are determined by his or her personal and emotional characteristics, i.e., they depend on self-esteem and anxiety level, which develop positively in the process of involving younger students in the educational dialogue, has been confirmed. Consequently, the technology of implementing a dialogical approach through the systematic involvement of students in the educational dialogue at the elementary school educational process will positively promote its edification.

The general tasks of teachers, the participants of the research, are acquiring knowledge in the field of psychology and pedagogy on the edification of education through the application of educational dialogue, general methodical techniques of collective-group and collective-frontal work, acquisition of competence in communication, and mastering the mechanisms of its introduction into the practice of primary education.

The COT 2 test questionnaire was used to study teachers' communicative and organizational skills, the testquestionnaire by Spielberg and Hanin was used to evaluate the levels of reactive and personal anxiety, the Balanced Emotional Empathy Scale (BEES) test by Megrabian and Epstein was applied, the methods of diagnostics of communicative control (Schneider) was applied, a test for self-assessment by Tsymbaliuk and Lozhkin was applied, and methods of diagnostics of barriers in establishment of emotional contacts by Boiko was used for questioning.

Studies of teachers' self-esteem, according to Tsymbalyuk and Lozhkin's method, showed that the dominant level in the experimental group of teachers with more than five years-experience is average at $65 \%$, and $54 \%$ for beginning teachers.

The results of the research were subjected to correlation analysis. For a $5 \%$ level of accuracy, which is generally accepted in psychological and pedagogical studies, the significant correlation coefficient, based on the amount of selection from 150 people, is $r=0,278711$ (calculated using PPP Statistica 5.0).

Correlation analysis helped to identify and better understand the combination and interference of self-esteem, a reactive and personal anxiety that characterizes those with low levels of communication skills Table 5 . Thus, it can be stated that communicative abilities, self-esteem, and anxiety levels are interrelated; lower self-esteem increases anxiety and decreases communication skills. 
Table-5. Results of correlation analysis of teachers' communicative abilities.

\begin{tabular}{l|c|c|c|c|c}
\hline Communicative abilities & $\begin{array}{c}\text { Communicative } \\
\text { abilities }\end{array}$ & $\begin{array}{c}\text { Organization } \\
\text { al abilities }\end{array}$ & $\begin{array}{c}\text { Reactive } \\
\text { anxiety }\end{array}$ & $\begin{array}{c}\text { Personal } \\
\text { anxiety }\end{array}$ & $\begin{array}{c}\text { Self- } \\
\text { esteem }\end{array}$ \\
\hline Communicative abilities & 1 & & & & \\
\hline Organizational abilities & 0,278756 & 1 & & & \\
\hline Reactive anxiety & $-0,49548$ & $-0,16289$ & 1 & & \\
\hline Personal anxiety & $-0,67367$ & $-0,41941$ & $-0,343662$ & 1 & \\
\hline Self-esteem & $-0,69792$ & $-0,30067$ & 0,432704 & 0,909868 & 1 \\
\hline
\end{tabular}

Correlation was found between the level of communicative ability and:

a) organizational skills $(\mathrm{r} \mathrm{CA}, \mathrm{OS}=0.288)$ - direct correlation.

b) reactive anxiety ( $\mathrm{r}$ short circuit, $\mathrm{RA}=0,495)$ - inverse correlation.

c) personal anxiety $(\mathrm{r} \mathrm{CA}, \mathrm{PA}=0,673)$ - inverse correlation.

d) self-esteem ( $\mathrm{r}$ SE, $\mathrm{CA}=0,698)$ - direct correlation (since in the tests high scores on communicative and organizational abilities meant high level, and high scores on self-esteem meant low level.

The correlation between organizational skills was also revealed and a) personal anxiety $(\mathrm{r}$ OS, PA = 0,419) inverse correlation and $b)$ self-esteem $(r \mathrm{OS}, \mathrm{SE}=0.301)$ is a direct correlation.

Reactive anxiety correlates with a) personal anxiety $(\mathrm{rPA}, \mathrm{RA}=0.344)$, where a direct correlation is detected, and b) self-esteem ( $\mathrm{r}$ RA, SE = 0,433), where an inverse correlation was detected. Personality anxiety also correlates with self-esteem $(\mathrm{r}$ PA, $\mathrm{SE}=0.91)$, and an inverse correlation is found. No statistically significant association was revealed between organizational abilities and reactive anxiety ( $\mathrm{r} \mathrm{OA}, \mathrm{RA}=0.1628$ ).

The detection technique of the affiliation level (Balanced Emotional Empathy Scale - BEES by Megrabian and Epstein) and the communication control diagnostics (Schneider) for studying the level of communicative control allowed us to identify two motivational trends, functionally associated with the need for affiliation, and therefore with the possibility of implementing edifying changes, namely the aspiration to people and fear of being neglected. Foreign researchers define the motive of affiliation as a complex psychological phenomenon, the content of which is heterogeneous and consists of the following needs: contact with people, be a member of the group, interact with others, provide and receive help. At the same time, the companionship (community) of other people allows him to check the chosen behavior and the nature of reactions to a complex and dangerous environment, which is especially important for the teacher as the organizer of the educational dialogue.

Analysis of the U-Mann-Whitney test and the degree of reliability of the data revealed that beginner teachers and teachers with more than five years of experience statistically significantly $(\mathrm{p} \leq 0.01)$ differ in sign "aspiration to acceptance," that is, teachers with experience are significantly more motivated to acceptance by others and the communicative function in education than the beginner teachers. According to the t-Student criterion, statistically significant $(\mathrm{p}<0.05)$ on the basis of "fear of rejection" is more present in teachers with experience (they have more fear of being rejected in comparison with beginner teachers).

Thus, there are reasons to believe that the introduction of a policy of edification regarding the educational process promotes the formation of communicative competence of the teacher, positively influencing, in particular, his affiliation.

The technique of diagnostics of "obstacles" in establishing emotional contacts, according to Boiko, provided an opportunity to investigate emotional obstacles in the establishment of emotional contacts - inability to operate emotions, to dose them, inability to express emotions, domination of negative emotions, and unwillingness to approach people based on emotions etc. Referring to this technique, you can identify the factors of communication barriers related to the emotional sphere. It allows us to set emotional obstacles along the way of making emotional contacts.

\section{Discussion}

At the beginning of the 21 st century, there was a continuation and consolidation, a technological implementation of the idea of dialogicity in the educational process by organizing the subject-subject interaction of younger students within the already created didactic technologies (Elkonin-Davydov's developmental training, problem dialogue technology, school of dialogue of cultures, game technologies of training, training on collectivedistributed basis, etc.). On this basis, the communicative competence of the younger student as a subject of educational dialogue is formed, and the didactic category "educational dialogue" becomes methodological in nature and turns into the objective basis of developmental learning as a concept.

The development of the dialogical speech of young school children occurs under the conditions of creating an active speech environment, during interaction with those around them, in parallel, in several systems, "child child," "child - adult," "child - peer."

Thus, educational dialogue is a special form of education edification, personally focused development of the educational environment, specially organized educational and cognitive activity, in which knowledge, skills, and abilities are formed; the communicative culture and culture of thinking of the person develop.

Only in a few works is educational dialogue considered as a process of organized communication in the context of the subjectivization of teacher activity. Integral technologies of its development in the educational process of the national elementary education have not been revealed; the communicative potential of learning, its organizational side, remains insufficiently illuminated. Instead, the efficiency of the educational process in modern schools, including primary school, is determined by a number of sociological regularities that are not always taken into account in the didactic interaction of its subjects: the development of an individual is determined by the development of all other individuals with whom he is in direct or indirect communication; productivity of learning depends on the volume and intensity of cognitive contacts; the training efficiency is determined by the level of "intellectual environment", the intensity of mutual learning; the effectiveness of training increases in the conditions of cognitive tensions caused by competition; the effectiveness of teaching depends on the quality of communication 
between the teacher and the students; didactogeny (consequences of incorrect teacher's attitude towards students) leads to a decrease in learning efficiency in general and regarding each student, in particular.

Pedagogical capabilities of the teacher of a new formation as organizer of the educational dialogue in formation of communicative skills of younger students are based on the fact that the educational dialogue covers all the possible list of communication skills provided by the curriculum; provides qualitative improvement of communicative skills and transfer them to atypical communication situations; encourages free choice of solution in educational activities; contributes to the formation of communication skills.

Existing research emphasizes that in order to organize an educational dialogue, it is necessary to: remove all barriers in communication between teacher and child and use invigorating techniques; possessing a technology that encourages and leads to dialogue; conducting observation lessons and problem lessons along with task-lessons; use of various dialogical receptions at the lessons: discussions, group work, "intellectual traps", etc.

\section{Conclusion}

1. Analysis of the theoretical and methodological foundations and global trends in the modern world showed that: - education must be, first of all, a practice of freedom, at first in reflecting on and discussing life situations, and then in socially significant action.

- the aim of all pedagogical efforts should be the life world of the student, an integral element of the culture of which is critical thinking.

- dialogue (polylogue) is an adequate means of achieving this goal.

- in postmodern society, education acts as the most important instrument for its transformation, a prerequisite for the way out of a civilized crisis and a condition for preventing anthropological catastrophe.

2. The historically formed idea of dialogue in the pedagogical and didactic plane is the basis of the edification of education as a whole, which provides the communicative nature of educational interaction through educational dialogue; determines the impact of educational dialogue as a means of the edification of primary education, and causes a change in the subjectivity of the student and teacher as participants in didactic interaction of a new type.

3. The main tasks of the teacher regarding edification of the educational activity through the use of educational dialogue are to acquire communication skills: the ability to come into contact with the interlocutor, to perceive and understand the emotional state of the student / students, to receive and transmit non-verbal information, to be a participant or leader of the discussion, ability to construct dialogue / polylogue correctly, to listen and understand the interlocutor, to adjust the relationship during the dialogue or polylogue; correction, formation and development of attitudes necessary for successful communication, resolution of conflict situations, development of emotional resilience to difficult life situations.

The adequate development of the ability and ful perception and evaluation of themselves and others, as well as the relationships that have developed between people, should encourage the teacher to constant psychological and general methodological self-improvement. An important component of a teacher's educational activity is the work with the emotional sphere, aimed at understanding, monitoring and comprehension of their emotions. Selfimprovement of pedagogical activity in conditions of edification should provide correction of affiliation as a basis in ensuring the communicative activity of the teacher-organizer of educational dialogue, development of personal qualities, formation of adequate self-esteem, self-awareness, and acceptance.

\section{References}

Aguiar, O. G., Mortimer, E. F., \& Scott, P. (2010). Learning from and responding to students' questions: The authoritative and dialogic tension. Journal of Research in Science Teaching: The Official Journal of the National Association for Research in Science Teaching, 47(2), 174-193. Available at: https://doi.org/10.1002/tea.20315.

Alexander, R. A., Hardman, F. C., \& Hardman, J. (2017). Changing talk, changing thinking: interim report from the in-house evaluation of the CPRT/Uo T Dialogic Teaching Project. Heslington, UK: University of York and Cambridge Primary Review Trust.

Antonenko, T. L., \& Bezugla, M. V. (2017). Spiritual and cultural values of education of student youth: monograph. Kyiv, Ukraine: Institute of Gifted Children of the NAPS.

Chai, C. S., Koh, J. H. L., Tsai, C.-C., \& Tan, L. L. W. (2011). Modeling primary school pre-service teachers' Technological Pedagogical Content Knowledge (TPACK) for meaningful learning with information and communication technology (ICT). Computers $\&^{\circ}$ Education, 57(1), 1184-1193. Available at: http://dx.doi.org/10.1016/j.compedu.2011.01.007.

Chala, Y. M., \& Shakhraychuk, A. M. (2018). Psychodiagnostics: A textbook. Kharkiv, Ukraine: NTU "KhPI".

Claro, M., Preiss, D. D., San MartíN, E., Jara, I., Hinostroza, J. E., Valenzuela, S., . . Nussbaum, M. (2012). Assessment of 21 st century ICT skills in Chile: Test design and results from high school level students. Computers E Education, 59(3), 1042-1053. Available at: http://dx.doi.org/10.1016/j.compedu.2012.04.004.

Darling-Hammond, L., \& Bransford, J. (2005). Preparing teachers for a changing world: What teachers should learn and be able to do. San Francisco, CA: Jossey-Bass.

Department for Education. (2013). The national curriculum in England: Key Stages 1 and 2 framework document. Retrieved from: https://assets.publishing.service.gov.uk/government/uploads/system/uploads/attachment_data/file/425601/PRIMARY_nation al_curriculum.pdf.

Felton, M., \& Kuhn, D. (2001). The development of argumentive discourse skill. Discourse Processes, 32(2-3), 135-153. Available at: https://doi.org/10.1080/0163853X.2001.9651595.

Haneda, M., Teemant, A., \& Sherman, B. (2017). Instructional coaching through dialogic interaction: Helping a teacher to become agentive in her practice. Language and Education, 31(1), 46-64. Available at: https://doi.org/10.1080/09500782.2016.1230127.

Hennessy, S., Dragovic, T., \& Warwick, P. (2017). A research-informed, school-based professional development workshop programme to promote dialogic teaching with interactive technologies. Professional Development in Education, 44(2), 145-168. Available at: https://doi.org/10.1080/19415257.2016.1258653.

Hennessy., S., Rojas-Drummond, S., Higham, R., Márquez, A. M., Maine, F., Ríos, R. M., . . Barrera, M. J. (2016). Developing a coding scheme for analysing classroom dialogue across educational contexts. Learning, Culture and Social Interaction, 9, 16-44. Available at: https://doi.org/10.1016/j.lcsi.2015.12.001.

Howe, C., \& Abedin, M. (2013). Classroom dialogue: A systematic review across four decades of research. Cambridge Journal of Education, $43(3), 325-356$.

Howe, C., \& Mercer, N. (2017). Commentary on the papers. Language and Education, 31(1), 83-92.

Lefstein, A., \& Snell, J. (2014). Better than best practice: Developing teaching and learning through dialogue. London, UK: Routledge.

Littleton, K., Mercer, N., Dawes, L., Wegerif, R., Rowe, D., \& Sams, C. (2010). Talking and thinking together at Key Stage 1. Early Years, 25(2), 167-182. Available at: https://doi.org/10.1080/09575140500128129

Littleton., K., \& Mercer, N. (2013). Interthinking: Putting talk to work. Abingdon, UK: Routledge. 
Macbeth, D. (2011). Understanding understanding as an instructional matter. Journal of Pragmatics, 43(2), 438-451. Available at: https://doi.org/10.1016/j.pragma.2008.12.006

Maton, K. (2013). Marking semantic waves: A key to accumulated knowledge-building [Ola semántica: Una clave para la construcción del conocimiento acumulado]. Linguistics and Education, 24(1), 8-22. Available at: https://doi.org/10.1016/j.linged.2012.1 1.005.

Mercer, N., \& Littleton, K. (2017). Dialogue and the development of children's thinking. London, UK: Routledge.

Michaels, S., O'Connor, C., \& Resnick, L. B. (2008). Deliberative discourse idealized and realized: Accountable talk in the classroom and in civic life. Studies in Philosophy and Education, 27(4), 283-297. Available at: https://doi.org/10.1007/s 11217-007-9071-1.

Nelson, K. (2017). Toward a more dialogic pedagogy: changing teachers' beliefs and practices through professional development in language arts classrooms. Language and Education, 31(1), 65-82. Available at: https://doi.org/10.1080/09500782.2016.1230129.

Pehmer, A.-K., Gröschner, A., \& Seidel, T. (2015). Fostering and scaffolding student engagement in productive classroom discourse: Teachers' practice changes and reflections in light of teacher professional development. Learning, Culture and Social Interaction, 7 , 12-27. Available at: https://doi.org/10.1016/j.lcsi.2015.05.001.

Pisanu, F., \& Menapace, P. (2014). Creativity \& innovation: Four key issues from a literature review. Creative Education, 5(03), 145-154. Available at: https://doi.org/10.4236/ce.2014.53023.

Pontefract, C., \& Hardman, F. (2005). Classroom discourse in Kenyan primary schools. Comparative Education, 41(2), 87-106. Available at: https://doi.org/10.1080/03050060500073264.

Rorty, R. (1979). Philosophy and the mirror of nature. Princeton, NJ: Princeton University Press.

Ruthven, K., Mercer, N., Taber, K. S., Guardia, P., Hofmann, R., Ilie, S., . . Riga, F. (2017). A research-informed dialogic-teaching approach to early secondary school mathematics and science: The pedagogical design and field trial of the epiSTEMe intervention. Research Papers in Education, 32(1), 18-40. Available at: https://doi.org/10.1080/02671522.2015.1129642.

Sedova, K., Sedlacek, M., \& Svaricek, R. (2016). Teacher professional development as a means of transforming student classroom talk. Teaching and Teacher Education, 57, 14-25. Available at: https://doi.org/10.1016/j.tate.2016.03.005.

Sepeng, P. (2011). Triadic dialogue: An analysis of interactions in multilingual Mathematics primary classrooms. Online Submission, 8(4), 412418.

Wu, Y.-T. (2013). Research trends in technological pedagogical content knowledge (TPACK) research: A review of empirical studies published in selected journals from 2002 to 2011. British Journal of Educational Technology, 44(3), 73-76. Available at: http://dx.doi.org/10.1111/i.1467-8535.2012.01349.x.

Yun-Jo, A., \& Reigeluth, C. (2012). Creating technology-enhanced, learner-centered classrooms: K-12 teachers' beliefs, perceptions, barriers, and support needs. Journal of Digital Learning in Teacher Education, 28(2), 54-62. Available at: https://doi.org/10.1080/21532974.2011.10784681. 